\title{
The Parol Evidence Rule in California
}

T IS provided in the California Code of Civil Procedure
that:
"When the terms of an agreement have been reduced to writing by the parties, it is to be considered as containing all those terms, and therefore there can be between the parties and their representatives, or successors in interest, no evidence of the terms of the agreement other than the contents of the writing, except in the following cases: (1) Where a mistake or inperfection of the writing is put in issue by the pleadings; (2) Where the validity of the agreement is the fact in dispute. But this section does not exclude other evidence of the circuinstances under which the agreement was made or to which it relates, as defined in section eighteen hundred and sixty, or to explain an extrinsic ambiguity, on to establish illegality or fraud. The term agreement includes deeds and wills, as well as contracts between parties."

Section 1625 of the Civil Code provides as follows:

"The execution of a contract in writing, whether the law requires it to be written or not, supersedes all the negotiations or stipulations concerning its natter which preceded or accompanied the execution of the instrument."

These sections are the only provisions in our codes expressly dealing with the so-called parol evidence rule.

The first fact to be borne in unind in considering this rule is that the doctrine is one of substantive law rather than of the law of evidence. This was first clearly explained by Professor Thayer in 1893. ${ }^{2}$

Professor Wigmore in his treatise on evidence also emphasizes the distinction. The rule, says the learned author, "does not exclude certain data because they are for one or another reason untrustworthy or undesirable means of evidencing some fact to be proved. It does not concern a probative mental process,- - the process of believing one fact on the faith of another. What the rule does is to declare that certain kinds of fact are legally ineffective in the substantive law; and this of course (like any other ruling of substantive law) results in forbidding the fact to be proved at all. But this prohibition of proving it is merely the dramatic aspect of the process of applying the rule

I Cal. Code Civ. Proc. \$ 1856.

2 The "Parol Evidence" Rule, 6 Harvard Law Review, 325. 
of substantive law. When a thing is not to be proved at all, the rule of prohibition does not become a rule of evidence merely because it comes into play when the counsel offers to 'prove' it or 'give evidence' of it; otherwise, any rule of law whatever might be reduced to a rule of evidence; a ruling (for example) that on a plea of self-defense in an action of battery no evidence of the plaintiff's insulting words is to be received, would become the legitimate progeny of the law of evidence."

This distinction is of more practical importance than may, at first sight, appear. This is made clear in the two California decisions which deal with the subject.

In a decision rendered by the District Court of Appeal in the case of Dollar v. International Banking Corporation, ${ }^{4}$ the court had said in commenting on the failure to object to the admission of certain parol evidence of the contents of a document: "No objection was made to the introduction of this testimony, but the incompetency of parol evidence to vary a writing may be considered as a matter of law."

In a petition for a rehearing it was claimed that the statement was incorrect and that secondary evidence of the contents of a written instrument should be considered by a trial court, when no objection was made to its introduction in evidence.

The District Court of Appeal in passing on the petition took occasion to point out the distinction in this regard between the parol evidence rule and the so-called best evidence rule. Said the court:

"Whether or not a contract in writing may be varied by parol evidence is a question of substantive law while the admission or rejection of secondary evidence is governed by the rules of evidence. By way of illustration of the distinction between the rule declared by this court and that cited by appellant, it may be said, that parol or secondary evidence, unobjected to, might supply the terms, or purport, of a contract which had been reduced to writing, and, in this form, furmish sufficient proof to sustain a finding, but parol evidence would neither be admissible to vary this contract, nor, if admitted without objection, be sufficient to support a finding which was in conflict with or which in any manner varied the original written contract which the parties entered into. The purpose of the rule relating to the varying of a writing by parol evidence is to prohibit this

3 Wigmore on Evidence, $\$ 2400$, (1).

4 (1910) 13 Cal. App. 331, 109 Pac. 449. 
from being done, while the rule relating to the admission of secondary evidence goes only to the form in which the evidence may be introduced."

The Supreme Court in the case of Harding v. Robinson ${ }^{5}$ also recognized the true nature of the parol evidence rule. In its opinion the court quoted with approval the following language of one of the Circuit Courts of Appeals:

"According to the modern and better view, the rule which prohibits the modification of a written contract by parol is a rule, not of evidence, but of substantive law."

Our Supreme Court further stated in its opinion that-

"By that law the solemn obligations of parties evidenced by their writings may not be modified or set aside for fraud unless the rules of this substantive law in pleading the fraud are duly complied with. Furthermore, when they have not been so complied with, not only is evidence inadmissible to effect such a modification of the contract, but if it be admitted, and that without objection of the opposing party, nevertheless, it is the duty of the court to disregard it utterly in reaching its decision."?

Since the rule is one of substantive law, it might appear that it should apply regardless of whether or not a question as to what constituted the actual agreement arose between the parties to the writing or between one of the parties and a third person. It is settled, however, that in the latter situation, the doctrine is not applicable and the writing may be varied by parol evidence. ${ }^{8}$

II.

Our Code of Civil Procedure enacts that "no evidence" of the terms of a writing may be given other than the contents of the writing in cases where the rule under discussion is applicable. The Civil Code also provides, it will be recalled, that the execution of a contract in writing "supersedes all the negotiations or stipulations concerning its matter which preceded or ac-

5 (1917) 175 Cal. 534, 166 Pac. 808.

- Pitcairn v. Philip Hiss Co. (1903) 123 Fed. 110, 61 C. C. A. 657.

7 Also see Lawrence v. Premier Indemnity Co. (July 5, 1919) $58 \mathrm{Cal}$. Dec. 51; Farmers' Bank v. Altura etc. Co. (1900) 129 Cal. 263, 61 Pac. 1077; and 2 California Law Review, 332. The early case of Tebbs v. Weatherwax (1863) $23 \mathrm{Cal}$. 58, is contra.

's Smith v. Moynihon (1872) 44 Cal. 53; Dunn v. Price (1896) 112 Cal. 46, 44 Pac. 354; Smith v. Goethe (1911) 159 Cal. 628, 115 Pac. 223; Spangenberg v. Nesbitt (1913) 22 Cal. App. 274, 124 Pac. 343.

○ 1856. 
companied the execution of the instrument."10 These provisions, ' it will be noted, are more restrictive than is the rule as it is commonly expressed, namely, that parol evidence is inadmissible to contradict or add to the terms of a written instrument. The term "parol evidence" is commonly regarded as practically synonymous with oral evidence. The rule under discussion prohibits the admission of more than that class of testimony. Other writings may be excluded when not embraced within the terms of the instrument that is finally agreed upon by the parties as incorporating all of the terms of their agreement. As Professor Thayer pointed out it is "extrinsic" evidence that is excluded regardless of the form that such evidence may take. ${ }^{11}$

Section 1625 of the Civil Code as originally drafted, provided that the execution of a contract in writing supersedes all the "oral" negotiations or stipulations concerning its matter which preceded or accompanied the execution of the instrument. It was amended in 1905 by striking out the word "oral."12

\section{III.}

Section 1836 of the Code of Civil Procedure further provides that the rule in question applies "when the terms of the agreement have been reduced to writing by the parties." This frequently raises a nice question as to whether or not the parties intended to reduce all the terms of their agreement to writing.

It is of course settled that where the writing presented to the court is obviously a mere memorandum, the rule excluding extrinsic evidence does not apply. ${ }^{13}$ Also when the writing is a mere receipt, though purporting to be "in full," the rule is not applicable. $^{14}$ The rule is otherwise, however, when the instrument though in form a receipt is in effect a contract. ${ }^{15}$ Likewise it is held that the rule has no application to a collateral

10 Cal. Civ. Code, $\$ 1625$.

116 Harvard Law Review 325, 331. Also see Wigmore on Evidence,

12 Cal. Stats. 1905, p. 611.

13 Johnson v. Powers (1884) 65 Cal. 179, 181, 3 Pac. 625, 626; Sivers v. Sivers (1893) 97 Cal. 518, 32 Pac. 571; Ames v. Southern Pacific Co. (1904) 141 Cal. 728, 75 Pac. 310, 99 Am. St. Rep. 98; Peterson v. Chaix (1907) 5 Cal. App. 525, 90 Pac. 948.

14 Winans v. Hassey (1874) 48 Cal. 634; Jersey etc. Co. v. Whitney (1906) 149 Cal. 269, 86 Pac. 509, 691.

${ }_{15}$ Jersey etc. Co. v. Whitney, supra, n. 14; Lawrence v. Premier Indemnity Co., supra, n. 7. 
agreement upon which the instrument is silent and which agreement does not purport to affect the terms of the writing. ${ }^{16}$

The mere fact that the instrument is silent on a certain subject is not always sufficient, however, to justify the admission of extrinsic evidence of the actual agreement of the parties. The parties may have intentionally excluded certain terms from the writing that was executed by them with the idea that such provisions should not constitute a part of their agreenent. When such was their intention, evidence dealing with those subjects upon which the writing is silent is inadmissible.

Moreover it is the settled rule that whatever the law implies from a contract in writing is as much a part of the contract as that which is expressed in it. Hence the writing cannot be varied as to what is implied any more than as to what is expressed. ${ }^{17}$

What then is the test to be applied in determining whether the parties to the written contract intended that the terms expressed therem should be exclusive? The question was passed on in the case of Harrison v. McCormick, ${ }^{18}$ in which the court said:

"The question whether a writing is upon its face a coinplete expression of the agreement of the parties is one of law for the court, and the rule which governs the court in its determination has been well stated as follows: 'If it imports on its face to be a complete expression of the whole agreement,--that is, contains such language as imports a coinplete legal obligation,-it is to be presumed that the parties have introduced into it every material itein and term; and parol evidence cannot be admitted to add another term to the agreement, although the writing contains nothing on the particular one to which the parol evidence is directed." "10

The doctrine of this case has been consistently followed by the Supreine Court since that time. ${ }^{20}$ It will be noted that the

${ }^{16}$ Sivers v. Sivers, supra, n. 13; Savings Bank v. Asbury (1897) 117 Cal. 96, 103, 48 Pac. 1081, 1083; Williams v. Ashurst Oil etc. Co. (1904) 144 Cal. 619, 78 Pac. 28; Piper v. Kellerman (1916) 32 Cal. App. 128, 162 Pac. 423.

17 Gardiner v. McDonogh (1905) 147 Cal. 313, 81 Pac. 964; Peterson v. Chaix, supra, n. 13; Standard Box Company v. Mutual Biscuit Company (1909) 10 Cal. App. 746, 751, 103 Pac. 938, 940; Smith-Booth-Usher Co. v. Los Angeles Ice etc. Co. (1917) 175 Cal. 136, 139, 165 Pac. 430, 431.

18 (1891) 89 Cal. 327, 26 Pac. 830, 23 Am. St. Rep. 469.

19 Citing Thompson v. Libby (1885) 34 Minn. 377, 26 N. W. 1. See also Naumberg v. Young (1882) 44 N. J. L. 339, 43 Am. Rep. 380.

20 Bradford Investment Company v. Joost (1897) $117 \mathrm{Cal} .204,48 \mathrm{Pac}$. 1083; Johnson v. Bibb Lumber Co. (1903) 140 Cal. 95, 98, 73 Pac. 730; Gardiner v. McDonogh, supra, n. 17; Empire Investment Company v. Mort (1915) 169 Cal. 732, 739, 147 Pac. 960, 963; Peterson v. Chaix, supra, n. 13. 
Supreme Court of Minnesota is cited by our Supreme Court as an authority for the rule that the answer to the question whether the writing is to be deemed complete must depend upon whether it purports upon its face to be complete. But the doctrine has since been abandoned in that jurisdiction. In a later case ${ }^{21,}$ the Minnesota Supreme Court said:

"While the writing itself is the only criterion by which the intention of the parties is to be ascertained, yet it is not necessary that the incompleteness of the writing should appear on its face from a mere imspection of it, for it is to be construed in the light of its subject-matter and the circumstances under which and the purposes for which it was executed:"

That the doctrine laid down by our Supreme Court on this subject is unsound would seem to have been made clear by $M r$. Wigmore." As he says : ${ }^{22}$

- Thether a particular subject of negotiation is embodied by the writing depends' wholly upon the intent of the parties thereto. ....This intent must be sought where always intent must be sought; namely, in the conduct and language of the parties and the surrounding circumstances.: The document alone will not suffice. What it was intended to cover cannot be known till we know what there was to cover: The question being. whether certain subjects of negatiations were intended to be covered, we must compare the writing and the negotiations before we can determine whether they were in fact covered. Thus the apparent paradox is committed of recelving proof of certain negotiations in order to determine whether to exclude them; and this doubtless has sometimes seemed to lower the rule to a quibble. But the paradox is apparent only. "The explanation, is that these alleged negotiations are received only provisionally. Although in form the witnesses may -be allowed to recite the facts, yet in truth the facts will be afterwards treated as immaterial and legally void, if the rule is held applicable. There is a preliminary question for the judge to decide as to the intent of the parties, and upon this he hears evidence on both sides; his decision here, pro or con, concerns merely this question preliminary to the ruling of law. If he decides that 'the transaction was covered by the writing, he does not decide that the excluded negotiations did 'not take place, but merely if they did take place they are nevertheless immaterial."

It would seem that such should be the, rule under the express

${ }^{21}$ Potter v. Easton (1901) 82 Minn. 247, 84 N: W: 1011.

22 Wigmore on Evidence; $\$ 2430$. Also see 17 Cyc. $746,-747$. 
language of our Code provision ${ }^{23}$ which provides that its terms "do not exclude other evidence of the circumstances under which the agreement was máde or to which it relates as defined in section 1860." That section provides that:

"For the proper construction of an instrument; the circumstances under which it: was made, including the situation of the subject of the instrument, and of the parties to it, may also be shown, so that the judge be placed in the position of those whose language he is to interpret."

Pursuant to the apparent purpose of these provisions the Supreme Court held in the case of Balfour v. Fresno etc. Company $^{24}$ that:

"For the purpose of determining what the parties intended by the language used, it is competent to show not, only the circumstances under which the contract was made, but also to prove that the parties intended and understood the language in the sense contended for; and for that purpose the conversation between and declarations of the parties during the negotiations at and before the time of the execution of the contract may be shown."

Again in the case of Snyder v. Holt Manufacturing Company ${ }^{25}$ the Supreme Court approved of the admission in evidence by the trial court of "prior negotiations" between" the parties notwithstanding the objection that the contract there involved purported on its face to be complete. This decision was followed by the District Court of Appeal in Lutweiler etc., Company v. Ukiah etc., Company. ${ }^{26}$. The court, in its opinion in that case, said :

"While parol evidence is not admissible to contradict or vary the written agreement, the court may look, not only to the language of the correspondence evidencing that transaction, but also to the subject matter of the agreement and the surrounding circumstances, in order to 'be placed, as nearly as practicable, in the position in which the contracting parties were when they entered into the agreement."

But the Supreme Court in denying a petition for a hearing by it took occasion to disapprove of that part of the opinion rendered by the District Court of Appeal, saying ${ }^{27}$ that:

23 Cal. Code Civ. Proc. \$ 1856.

24 (1895) 109 Cal. 221, 41 Pac. 876.

25 (1901) $134 \mathrm{Cal}$. 324, 66 Pac. 311.

26 (1911) 16 Cal. App. 198, 116 Pac. 707.

27 At 16 Cal. App. 210, 116 Pac. 712. 
". .... if the opinion of the District Court of Appeal can be construed as holding that a new term can be added to a written contract containing in itself all the essentials of a complete agreement, by resort to the antecedent oral negotiations of the parties, regarded as surrounding circumstances, we do not approve that doctrine, and do not regard it as essential to sustain the judgment of affirmance."

In the case of United Iron Works v. Outer Harbor Dock and Wharf Company ${ }^{28}$ the case of Snyder v. Holt Manufacturing Company ${ }^{29}$ was cited as authority permitting the introduction of parol evidence of "surrounding circumstances" for the purpose of showing that the parties had not intended to embody all the terms of their agreement in the writing executed by them. The Supreme Court held the evidence inadmissible and said of the case cited:

"We need not be at pains to discuss this case to the end of determining whether or not appellant's position in this regard is well founded. Suffice it to say that if such a construction is permissible the principle is so contrary to all adjudications, our own as well as those elsewhere, that it cannot be recognized as authority."

Speaking of the langnage of section 1860 of the Code of Civil Procedure the court said:

"This rule of evidence is invoked and employed only in cases where upon the face of the contract itself there is doubt and the evidence is used to dispel that doubt, not by showing that the parties meant something other than what they said but by showing what they meant by what they said." 30

The construction of section 1860 of the Code of Civil Procedure as allowing a resort to surrounding circumstances "only in cases where upon the face of the contract itself there is doubt and the evidence is used to dispel that doubt," would appear to be unnecessarily strict. It is worthy of note that the Supreme Courts of both North and South Dakota, which states have statutory provisions identical with ours, have not found it necessary to restrict the language of their code sections as our Supreme Court has done. In those states evidence of the prior negotiations of the parties is admitted for the purpose of en-

28 (1914) 168 Cal. 81, 141 Pac. 917.

29 Supra, n. 25.

30 Cf. Madera etc. Co. v. Livermore Co. (1918) 56 Cal. Dec. 351 ; 3 California Law Review, 86. 
abling the court to determine whether the parties intended the terms of their writing to be exclusive, notwithstanding the fact that the writing purports on its face to be complete. ${ }^{31}$

\section{IV.}

Section 1856 of the Code of Civil Procedure provides, it will be recalled, that the rule excluding extrinsic evidence of the terms of the writing does not apply where a mistake or imperfection of the writing is put in issue by the pleadings, nor where the validity of the agreement is the fact in dispute, nor where the purpose of the action is to establish illegality or fraud.

The general rule is that in cases where a mistake is relied upon, evidence of such mistake is only admissible where it was one of fact and not of law. ${ }^{32}$ Such was the law in this State at one time. ${ }^{33}$ Under the provisions of the Civil Code, however, a mistake of law may, under certain circumstances, successfully be interposed. ${ }^{34}$

It is not essential in order to show that a mistake has been made that the suit be one for the express purpose of securing a reformation of the writing. As the Code Commissioners said: "Under the Code of Procedure it is not necessary that the contract should be reformed, but it should be construed according to the actual intent of the parties."35 In any action in which the agreennent is directly involved and a mistake in its terms is set up as a defense, the court may ascertain the actual intention of the parties to it and disregard the erroneous parts of the writing. ${ }^{38}$ But a court may not in the absence of a showing of a right of reformation find upon oral testimony that an agreement included provisions which do not appear upon the face of the writing executed by the parties and enforce such provisions as a part of the written contract. ${ }^{37}$

31 DePue v. McIntosh (1910) 26 S. D. 42, 127 N. W. 533; Putnam v. Prouty (1913) 24 N. D. 517,140 N. W. 93.

3217 Cyc. 705.

${ }^{33}$ Smith v. McDougal (1852) 2 Cal. 587; Boggs v. Fowler and Hargrave (1850) 16 Cal. 559.

34 Cal. Civ. Code \& 1576.

85 Cf. Code Commissioners' note to Cal. Civ. Code $\S 1640$.

36 Lassing v. James (1895) 107 Cal. 348. 40 Pac. 534; Gardner v. California Guarantee Investment Co. (1902) 137 Cal. 71, 69 Pac. 844. But cf. Irving v. Cunningham (1884) 66 Cal. 15, 4 Pac. 766; Third St. Imp: Co. v. Mel elland (1913) 23 Cal. App. 369, 137 Pac. 1089. In these latter cases the court apparently overlooked our code prevision.

${ }^{37}$ Bradbury v. Higginson (1914) 167 Cal. 553, 140 Pac. 254. 
An exception to the rule that mistake must be put in issue by the pleadings is found in cases of what have been termed misdescriptions, a part of the description in a writing being-correct and the remainder incorrect. This form of mistake is generally regarded as constituting a latent ambiguity and will be treated by us hereinafter as such.

The mere fact that a person signed a writing without reading it in a mistaken belief as to its contents is not such a mistake as will be allowed to overtum the instrument. Our Supreme Court has this stated the rule:

"Where a person enters into an obligation with another upon an equal footing, $i$. "e., where he does so free from Wany fraud "practiced upon him, "and" not being under any $\therefore:$ undue influence, and there are no relations of confidence and trust, and the means of knowledge are equally ;open to both, and he executes the instrument without reading it or having it read to him, and without exercising the means of knowledge open to hin-neither the courts of law nor courts of equity will relieve him from the effects of 'his folly." ${ }^{38}$.

The fact that the party so signing the writing was illiterate is not sufficient to avoid the application " of the rule. He should, in 'such a case, have it read to him by someone in whom he had a right to place confidence.

This rile is subject to the qualification, however, that relief will be granted though the party signing was negligent if the other party knew or suspected the mistake.40

"Where the conterits of $a$ writing are 'misstated by the adverse party or by his agent, and the person who signed it had a right to rely upon the statement of such person the inistake may be shown, though the party complaining had not read the document before signing it.11 : This is true even though the party who signed was able to read the docuinent, "but neglected to do so. ${ }^{42}$ -It has also beeñ held thät, in cases "where a writing was pre-

38 Placer Co. Bank v. Freeman (1899) 126 Cal. 90, 94, 58 Pac. 388. Accord, Metropolitan Loan Assn. 'v'. Esche (1888) 75 Cal. 513, $17 \mathrm{Pac}$. 675; Kimmell v. Skelly (1900) 130 Cal. 555, 62 Pac. 1067 ; Harding v. Robinson, supra, n. 5; Burt v. L. A. etc. Assn. (1917) 175 Cál. 668, 166 Pac. 993.

- 39 Hawkins v. Hawkins (1875) 50 Cal 558; Schmidt y. Bekins etc. Co. (1915) 27 Cal. App. 667; 155 Pac, 647.

s0 Wilson v. Moriarity (1891) 88 Cal. 207,26 Pac. 85 ; L. A. Co. v. New Liverpool Co. (1906) 150 Gal: 21, 87. Pac. 1029.

${ }_{41}$ Meyer v. Haas : (1899) $126 \mathrm{Cal}$. 560, $58 \cdot \mathrm{Pac} .1042 ;$

\$2 Calmon : X. Sarraille (1904) 142 Cal. 638, 76. Pac. 386. 
pared by the adverse party and its terms are so expressed as not to be intelligible to the person signing it but who signs in reliance on the statement made to him as' to its accuracy, 'parol testimony of such facts is admissible for the purpose of raising an estoppel against the use of the document by the adverse party. 43 ,

The same principle of estoppel has been applied in actions against insurance companies' where the insured 'gave the company's agent 'correct answers to the 'questions' asked in the printed application for insurance, but the agent incorrectly wrote in the answers; and the applicant signed the application without reading it."4

In the case of Conklin v: Benson ${ }^{45}$ our Supreme Court recognized the doctrine that where a person who has no intention of selling his property is ${ }_{i}$ induced by some trick or device to sign a paper having such effect, believing that paper to be a substantially different instrument, the paper so signed is in effect as much a forgery as it would have been had the signature-actually been forged: : The court, however, distingnished the facts in the case before it upon the ground that the plaintiff fully understood that she was signing papers which would convey all her interest in the property involved, and that the difference between the papers she thought she' was signing and the 'papers she actually signed was merely one of detail-one set of papers having precisely the same ieffect as the other, i: e.; the conveyance of her interest in her property:

In all of the cases cited above which involved fraud exercised on the party signing; it was alleged that such person was deceived as to the nature of the document. The extrinsic evidence of the fraudulent representations is allowed in such cases, not as a defense for the purpose of upsetting an agreement that was actually entered into, but for the purpose of showing that no such agreement as that offered in evidence was ever made by the person who signed the document. ${ }^{48}$. Misrepresentations other than as to the contents of the document or going rather to the motives for making the contract than to its existence may be admissible or not, depending on' the substantive law as to what

43 Maxsón v. Llewellyn (1898) 122 Cal. 195, 54 Pac. 732; Providence Jewelry Co. v. Nagel (1910) $157 \mathrm{Cal} .497,108 \mathrm{Pac} .312$.

\$4 Lyon vinited Moderns (1906) 148 Cal. 470, 83 Pac. 804, 4 L. R. A.

(N. S.) 247,113 Am. St. Rep. 296.

45 (1911) 159 Cal. 785,116 Pac. 34.

to Meyer v. Haas, supra, n. 41. 
misrepresentations will avail to avoid an agreement actually entered into.

Although the writer has not found any California cases in which the theory has been distinctly enunciated, it is the general rule that it may be shown by extrinsic evidence that although a party signed the writing in controversy, it was understood at the time that it should not become operative or binding upon him until soine condition precedent, not appearing upon the face of the writing, was complied with."7

Such a case is to be distinguished from one involving a condition subsequent on the non-perfornance of which the written agreement shall become void. Such an understanding may not be shown, as the execution of the agreenent is thereby admitted, and the attempt is to add to its terms a provision not found in the writing. ${ }^{48}$ In the former case, the evidence is adinitted solely for the purpose of showing that no agreenent was ever consummated.

Although this principle has not been expressly stated in California, an application of it is found in the settled rule that it may be shown that a deed on other instrument was delivered in escrow to take effect upon the perfornance of a certain condition. ${ }^{49}$ The non-performance of the condition nay not be shown, however, when the delivery was to the grantee himself. ${ }^{50}$

There have been several other decisions in this State involving facts which came near to constituting conditions precedent but which were decided on another ground. Thus in the case of Billings v. Everett, ${ }^{51}$ the maker of a promissory note was perinitted in an action brought on the note to show that he had given it in consideration of the oral promise of the payee to dig an irrigation ditch across the land of the former, which was to be coinpleted by a certain date, it being understood that if the ditch was not completed by that time, the inaker should not be liable on the note. The Supreme Court held that the evidence

\footnotetext{
47 Wigmore on Evidence, $\$ 2408-2410$; Williston's Wald's Pollock on Contracts, p. 311 .

48 Stanley v. White (1896) 160 Ill. 605, 43 N. E. 729.

49 Cannon v. Handley (1897) 72 Cal. 133, 13 Pac. 315; McDonald v. Huff (1888) 77 Cal. 279, 19 Pac. 499; Wittenbrock v. Cass (1895) $110 \mathrm{Cal}$. 1, 42 Pac. 300; Drinkwater v. Hollar (1907) 6 Cal. App. 117, 91 Pac. 664. 50 Cal. Civ. Code § 1056; Bias v. Reed (1914) 169 Cal. 33, 145 Pac. 516. But cf. Black v. Sharkey (1894) 104 Cal. 279, 37 Pac. 939. The doctrine laid down in Bias v. Reed has been criticized by Mr. Wigmore; cf. Wigmore on Evidence, \$ 2408.

51 (1878) 52 Cal. 661.
} 
was admissible for the purpose of showing a failure of consideration. $^{.2}$

The same doctrine was applied in a subsequent case notwithstanding the fact that the completion of the work for which the note was given was expressly termed by the Supreme Court, "an absolute condition precedent" to the note's becoming effective. ${ }^{58}$

The Supreme Court has, however, limited the doctrine admitting parol evidence for the purpose of showing the failure of a consideration expressed in the writing, and has refused to allow the evidence for the purpose of proving an additional consideration not expressed in the writing and a failure thereof. ${ }^{54}$

The Code of Civil Procedure provides, ${ }^{55}$ it will be recalled, that extrinsic evidence is admissible in cases of fraud and mistake and of imperfections in the writing and also where the validity of an agreement is the fact in dispute. By implication it would appear that in other cases such evidence should not be admissible. We have seen that such evidence is admissible for the purpose of showing a condition precedent to the writing becoming effective. There are other cases in which extrinsic evidence is also allowed which are not covered by the letter of the statute. An instance of this is found in the application of the rule that what purports to be a deed may be shown to have been intended inerely as a mortgage. This is allowed, as pointed out by Mr. Justice Field, upon the theory that the evidence does not contradict or vary the instrument but shows facts dehors the instrument, which create an equity superior to its terms. ${ }^{5 B}$

Parol evidence is likewise admitted upon the same theory for the purpose of showing that a deed conveying property was intended to create a trust in the grantee, ${ }^{57}$ and also to show that a written assignment of personal property though absolute on its face was in fact made in trust for the benefit of others than the assignee. ${ }^{58}$

Moreover, even though there was no fraud or mistake in con-

52 Jefferson v. Hewitt (1894) 103 Cal. 624, 37 Pac. 638; Muir v. Hamilton (1908) 152 Cal. 634, 636, 93 Pac. 857, 858; accord.

${ }_{53}$ McLaughlin v. Clausen (1890) 85 Cal. 322, 24 Pac. 636.

54 Langan v. Langan (1891) 89 Cal. 186, 26 Pac. 764.

$55 \S 1856$.

58 Pierce v. Robinson (1859) 13 Cal. 116, 131. Cf. 2 California Law Review, 147.

57 Brison v. Brison (1888) 75 Cal. 525, 17 Pac. 689, 7 Am. St. Rep. 189.

58 Lockwood v. Canfield (1862) 20 Cal. 126. 
nection with the execution of the writing, nevertheless, if one party to it attempts to enforce it for a different purpose than that for which it was actually given and contrary to an oral understanding had between the parties at the time of the execution of the writing, parol evidence of such understanding is admissible. The reason given is that to sanction the use of the writing for the purpose expressed in it, in the face of the parol agreement, would be to uphold fraud and bad faith. ${ }^{59}$

\section{V.}

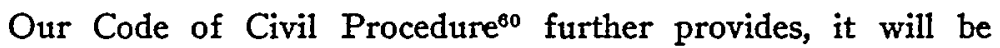
recalled, that evidence is admissible to explain "an extrinsic ainbiguity." Thus has been perpetuated the obsolescent distinction of Lord Bacon between latent and patent ambiguities.

"There be two sorts of ambiguities of words; the one is ambiguitas patens, and the other, latens: patens is that which appears to be ambiguous upon the deed or instrument; latens is that which seemeth certain and without ambiguity, for anything that appeareth upon the deed or instrument; but there is some collateral matter out of the deed that breedeth the ambiguity. Ambiguitas patens is never holpen by averment, and the reason is, because the law will not couple and iningle matter of specialty, which is the higher account, with matter of averment, which is of inferior account in law; for that were to make all deeds hollow, and subject to averment, and so, in effect, that to pass without deed, which the law appointeth, shall not pass but by deed. Therefore, if a man give land to J. D., et J. S., et haeredibus, and do not limit to whether of their heirs, it shall not be supplied by averment to whether of them the intention was the inheritance should be limited. But if it be ambiguitas latens, then otherwise it is; as if I grant my manor of S. to J. F. and his heirs, here appeareth no ambiguity at all; but if the truth be that $I$ have the manors both of south $S$ and north S., this ambiguity is matter in fact; and, therefore, it shall be holpen by averment, whether of them was that the party intended should pass."

Many courts today agree with Professor Thayer that "Bacon's Maxim was an unprofitable subtlety. In truth the only patent

59 Murray v. Dake (1873) 46 Cal. 644; Martin v. Parsons (1874) 49 Cal. 94; Isenhoot v. Chamberlain (1881) 59 Cal. 630; Eva v. McMahon (1888) 77 Cal. 467, 19 Pac. 872; accord.

00 \& 1856.

${ }^{61}$ Quoted in Mesick v. Sunderland (1856) 6 Cal. 297, 312. 
ambiguity that was not open to explanation by extrinsic matter was one that in the nature of things was not capable of explanation. Anything which was capable of it might be explained."'22

As early as 1858, Mr. Justice Field quoted the following language with approval:

"It will not do to say, therefore, that a patent ambiguity (meaning thereby merely an ambiguity patent or appearing on the face of the instrument) cannot be explained by evidence aliunde; though such remarks are frequently found in the books." os

But the distinction between latent and patent ambiguity having been recognized in our code, it is, of course, found in our cases. The rule is now said to be settled that parol evidence is admissible to explain or remove a latent ambiguity, ${ }^{84}$ but not ordinarily to cure a patent ambiguity. ${ }^{\text {Bs }}$

The rule excluding parol evidence in the case of patent ambiguities is not however, an unyielding one, as was pointed out by Justice Field. In fact, the exceptions are so well recognized in this State as to make it doubtful whether it can properly be said that there is any general rule at the present day excluding extrinsic evidence in the case of patent ambiguities. Thus in the case of Preble v. Abrahams ${ }^{68}$ the Supreine Court had occasion to pass upon the admissibility of extrinsic evidence for the purpose of explaining the meaning and intention of the parties in contracting for the sale of "forty acres of the eighty-acre tract at Biggs." It was held that the evidence was admissible. The court stated : $:$ ?

"Parol evidence is always admissible to explain the surrounding circumstances, and situation and relations of the p. 424 .

62 Thayer, Preliminary Treatise on Evidence at the Common Law,

63 Jenny Lind Co. v. Bower (1858) 11 Cal. 194, 199.

64 Mesick v. Sunderland, supra, n. 61; Brannan v. Mesick (1858) 10 Cal. 95; Piper v. True (1869) 36 Cal. 606; Board of Education v. Keenan (1880) 55 Cal. 642; Estate of Donnellan (1912) 164 Cal. 14, 127 Pac. 166; Fireman's Fund Insurance Co. v. Aachen etc. Ins. Co. (1906) 2 Cal. App. 690, 88 Pac. 1098.

6s Mesick v. Sunderland, supra, n. 61; Brannan v. Mesick, supra n. 64; People v. S. F. Savings Union (1866) 31 Cal. 132; Poorman v. Mills \& Co. (1870) 39 Cal. 345, 2 Am. Rep. 451; Brandon v. Leddy (1885) 67 Cal. 43, 7 Pac. 33; Hall v. Bartlett (1910) 158 Cal. 638, 112 Pac. 176; Walker v. City of Los Angeles (1914) 23 Cal. App. 634, 139 Pac. 89; Scott v. Woodworth (1917) 34 Cal. App. 400, 167 Pac. 543. Cf. Union Lumber Co. v. Simon (1907) 150 Cal. 751, 89 Pac. 1077.

${ }_{60}$ (1891) 88 Cal. 245, 26 Pac. 99, 22 Am. St. Rep. 301.

67 At p. 250. 
parties, at and immediately before the execution of the contract, in order to connect the description with the only thing intended, and thereby to identify the subject-matter, and to explain all technical terms and phrases used in a local or special sense."

The following language of Professor Pomeroy was quoted with approval : 68

- "It is not strictly accurate to say that the subject-matter must be absolutely certain from the writing itself, or by reference to some other writing. The true rule is, that the situation of the parties and the surrounding circumstances, when the contract was made, can be shown by parol evidence, so that the court may be placed in the position of the parties themselves; and if then the subject-matter is identified, and the terms appear reasonably certain, it is enough."

This case has also several times been approved by the Supreme Court. ${ }^{69}$

Recently the Supreme Court intimated that the rule excluding parol evidence in the case of patent ambiguities is not inflexible. Said that court in the case of Payne v. Commercial National Bank of Los Angeles:70

"It may not be correct to say that a prima facie patent ambiguity can never be explained by evidence aliunde, for it may be that such evidence will sometimes show that the apparent uncertainty in the language used does not in truth exist."

There are numerous cases in this State holding that extrinsic evidence is admissible to identify the subject-matier of an agreement, where it is referred to in indefinite terms. ${ }^{71}$

An ambiguity may appear in a writing by reason of a misdescription, a term appearing which, when applied to the subjectmatter, is found not to fit in all respects. The general rule in such cases is that extrinsic evidence of the circumstances under which the writing was executed may be admitted and the doubtful

${ }^{68}$ At p. 251.

69 Towle v. Carmelo etc. Co. (1893) 99 Cal. 397, 33 Pac. 1126; Higgins v. Manson (1899) $126 \mathrm{Cal}$. 467, 58 Pac. 907, 77 Am. St. Rep. 192; Brewer v. Horst Co. (1900) 127 Cal. 643, 60 Pac. 418, 50 L. R. A. 240; Joyce v. Tomasini (1914) 168 Cal. 234, 142 Pac. 67.

70 (1917) 177 Cal. 68, 169 Pac. 1007.

71 Ontario D. F. G. Assn. v. Cutting F. P. Co. (1901) 134 Cal. 21, 66 Pac. 28, $86 \mathrm{Am}$. St. Rep. 231; Gardiner v. MicDonough, supra, n. 17; Germain Fruit Co. v. Armsby Co. (1908) 153 Cal. 585, 96 Pac. 319 ; Willmon v. Peck et al (1907) 5 Cal. App. 665, 91 Pac. 164; Sanchez v. Yorba (1908) 8 Cal. App. 490, 97 Pac. 205. 
term of the writing applied to such person or thing as is aptly described by part of the description. ${ }^{72}$

This situation is most frequently presented in cases of inaccurate descriptions in deeds. Thus where a conveyance described a right of way as "a way to, in and for the ditch called Mountain Brow Water Company" and also as extending over "land owned by Spicer" and the second description was false, it was held that the latter description could be rejected. ${ }^{73}$ This doctrine has been embodied in the Code of Civil Procedure, ${ }^{74}$ which provides that:

"Where there are certain definite and ascertained particulars in the description, the addition of others which are indefinite, unknown, on false, does not frustrate the conveyance, but it is to be construed by the first-mentioned particulars."

The same principle has been applied in the cases of a misdescription of a devisee named in a will. ${ }^{75}$

As was pointed out above, the Code of Civil Procedure ${ }^{76}$ provides that for the purpose of explaining an ambiguity, the circumstances under which it was made, including the situation of the subject of the instrument and of the parties to it, may be shown. As we have seen, however, this language has been construed as applicable only to cases where upon the face of the instrument itself there is doubt and the evidence is used to dispel that doubt. ${ }^{77}$ But it has been frequently held if the language be fairly susceptible of either of two interpretations contended for without doing violence to its usual and ordinary import or to some established rule of construction, then an ambiguity arises, in which case extrinsic evidence may be resorted to for the purpose of explanation. In the leading case in which this rule was enunciated, it was also recognized that:

"For the purpose of determining what the parties intended by the language used, it is competent to show not only the circumstances under which the contract was made but also to prove that the parties intended and understood the lan-

72 Wigmore on Evidence, $\S 2476$.

${ }^{73}$ Reed v. Spicer (1864) 27 Cal. 57; Irving v. Cunningham (1884) 66 Cal. 15, 4 Pac. 766; Hall v. Bartlett (1910) 158 Cal. 638, 112 Pac. 176; accord.

$74 \$ 2077-1$.

75 Estate of Donnellan, supra, n. 64.

78 \& 1860 . n. 28.

77 United Iron Works v. Outer Harbor Dock \& Wharf Co., supra, 
guage in the sense contended for, and for that purpose the conversation between and declarations of the parties during the negotiations at and before the time of the execution of the contract may be shown."78

The rule that extrinsic evidence may be resorted to for the purpose of explaining the sense in which language susceptible of either of two interpretations in fact was used has frequently been laid down. ${ }^{70}$

Thus where a will purports to make a gift to "children" and it appears that no children were living at the time of the execution of the will, extrinsic evidence may be given to show that a gift to grandchildren was intended..$^{80}$

The Code of Civil Procedure ${ }^{81}$ also provides that:

"The terms of a writing are presumed to have been used in their primary and general conception, but evidence is, nevertheless, admissible that they have a local, technical, or otherwise peculiar signification and were so used and understood in the particular instance, in which case the agreement must be construed accordingly."

It was held prior to the adoption of the code that allowing extrinsic evidence of the meaning of terms or expressions peculiar to a particular business does not violate the rule that patent ambiguities cannot be explained by parol. ${ }^{83}$

The cases in this State dealing with the question whether it can be shown that by reason of a custom or usage in a special line of business a meaning out of the ordinary should be given to a term in a writing are by no means clear. In two early California decisions the well-known English case of Smith v. Wilson $^{84}$ was cited with approval. ${ }^{85}$ In that case it was held that parol evidence was admissible to show that by the custom of the

78 Balfour v. Fresno Co., supra, n. 24.

79 Williams v. Ashurst Oil etc. Co., supra, n. 16; Estate of Bell (1908) 153 Cal. 331, 95 Pac. 372; Jersey Farm Co. v. Atlanta Realty Co. (1912) 164 Cal. 412, 129 Pac. 593; Firemen's Fund Ins. Co. v. Aachen Ins. Co., supra, n. 64; Peterson v. Schaix, supra, n. 13; S. F. Clearing House v. MacDonald (1912) 18 Cal. App. 212, 122 Pac. 964.

80 In re Schedel (1887) 73 Cal. 594, 15 Pac. 297; Rhoton v. Bleven (1893) 99 Cal. 645, 34 Pac. 513 ; Estate of Willson (1915) 171 Cal. 449, 153 Pac. 927.

81 \& 1861.

82 Cf. also Cal. Code Civ. Proc. $\$ \S 644,1645$.

83 Reamer v. Nesmith (1868) 34 Cal. 624.

84 (1832) 3 B. \& Ad. 728, 110 Eng. Rep. R. 266. n. 83 .

${ }^{85}$ Jenny Lind Co. v. Bower, supra, n. 63 ; Reamer v. Nesmith, supra, 
country the word "thousand" might be construed as meaning twelve hundred. Likewise in the case of Morrison v. Wilson ${ }^{88}$, the court stated that:

"The question then comes to this, have the parties to a written contract the right to set aside the general sense of the words which they use, and for the purposes of the contract to assign to them another and different meaning, by convention? That they have both the right and the power to do this there can be no question. ..... If they see fit to agree that mile shall stand for leagne, or grant, bargain and sell for quitclaim, or even black for white, however we might marvel at the caprice, we could not question the power."

In the case of Callahan v. Stanley ${ }^{87}$ the Supreme Court had occasion to pass upon a lease which provided that the "stubble" of the grain grown by the tenant should belong to the landlord. The landlord sought to introduce evidence that by the custom of the country "stubble" included and designated whatever grain was left on the ground uncut after the harvest. The tenant objected on the ground that the term "stubble" was not obscure in meaning and was defined to mean "The stumps of wheat, rye, barley, oats or buckwheat left in the ground; the part of the stalk left by the scythe or sickle." The Supreme Court held the evidence admissible, saying:

"If there was an existing usage among farmers as to the meaning of the word 'stubble,' when this contract was made, it must be imferred that the contracting parties, being farmers, contracted with reference to it, and that they used the word in the broader meaning which was given to it by that usage, and not in the ordinary or popular sense. Evidence of such usage and meaning was, therefore, admissible to define and explain the peculiar and local meaning of the word as it was used in the contract, and the court below should have overruled the objection to the offer made by the plamtiff."

In the case of Higgins v. California etc. Company, ${ }^{88}$ it was held that evidence to show that the term "gross ton" was intended to have a special meaning other than that given to it by the Political Code was inadmissible. The court based its decision on the ground that there was nothing in the instrument indicating an intention to give to the term the special meaning

86 (1866) 30 Cal. 344, 348.

87 (1881) 57 Cal. 476.

88 (1895) 109 Cal. 304, 41 Pac. 1087. 
contended for, and that, moreoven, the practical construction of the parties indicated that they intended the phrase to bear its ordinary meaning.

The same contract came before the Supreme Court for construction a few years later in Higgins v. California Petroleum Company. ${ }^{89}$ The trial court had found that the term "gross ton" was used as meaning twenty-two hundred forty pounds. The appellant contended that the term was defined by statute, and, being unambiguous, parol evidence for the purpose of proving that the term carried another meaning was inadmissible. The court held that the provisions of section 1861 of the Code of Civil Procedure were as applicable to a term indicating a statutory weight as to any other term in a writing. Since the appeal was on the judgment roll, the court held that evidence might have been properly introduced before the trial court showing that a custom or usage existed; that the meaning contended for had been given to the term "gross ton," and that for the purpose of supporting the judgment, it would be presumed that such evidence had been introduced.

But in the case of Hale Bros. v. Milliken, ${ }^{90}$ evidence that in the structural steel business there existed a custom whereby the term "pound" was given a special meaning different from that given to it by the Political Code was held to be inadmissible, although the contract was made between dealers in that material. The court distinguished the case of Higgins v. California Petroleum Company" on the ground that the word "gross" in the phrase "gross ton" there involved was not used in the statute and had no legal signification; whereas the word "pound" was defined by the statute. The District Court of Appeal further stated that the Supreme Court had expressed the rule applicable too broadly in its decision. The conclusion of the former court was that contracts will be conclusively presumed to have been made in reference to the statute, unless the parties themselves have agreed or indicated in their contracts that their execution is to be governed by some usage of trade or custom prevailing in the community where they were made or their terms are to be per-

89 (1898) 120 Cal. 629, 52 Pac. 1080.

90 (1907) 5 Cal. App. 344, 90 Pac: 365 . A petition for rehearing by the Supreme Court was denied by that body. Accord, Standard American Dredging Co. v. Oakland (1916) 30 Cal. App. 237, 157 Pac. 833.

1 Supra, n. 89. 
formed. The court also enunciated the broad rule that evidence cannot be introduced of a custom or usage when the same contradicts the plain and unambiguous words of a written contract.

It is true that the rule has been laid down by the Supreme Court that it is not competent to vary or contradict a written contract by parol proof of a custoin when the contract is certain in its terms. ${ }^{92}$ But a court cannot tell whether or not the writing is certain in its terms until it has provisionally admitted evidence offered, which tends to prove that the terms used have a local or otherwise peculiar signification ${ }^{93}$ and were actually understood and used in that particular sense. In other words, evidence going to questions as to the meaning of the language employed in the light of a special usage, should be admitted. But if after the evidence is introduced and considered the court concludes that no such meaning attaches to the language employed, or, that it was not used and understood by all the parties in that peculiar sense, the evidence should be disregarded. ${ }^{24}$

The rule followed by many courts, and apparently applied by the District Court of Appeal in the case of Hale Bros. v. Milliken $^{95}$ is that evidence cannot be introduced to vary an apparently plain meaning.

But in this State, as has been pointed out, the code provides ${ }^{96}$ that proof that parties knowingly used a term in a sense not usually given to it is admissible.

Mr. Wigmore considers the rule against disturbing a plain meaning to be unsound in theory and in most cases objectionable from the standpoint of policy. ${ }^{97}$

Mr. Justice Holmes does not go so far. Says that distinguished jurist:

"I do not suppose that you could prove for purposes of construction as distinguished from avoidance, an oral declaration or even an agreement that words in a dispositive instrument, making sense as they stand, should have a different ineaning from the common one; for instance, that the parties to a contract orally agreed that when they wrote five hundred feet it should mean one hundred inches, or that Bunker Hill Monument should signify Old South Church.

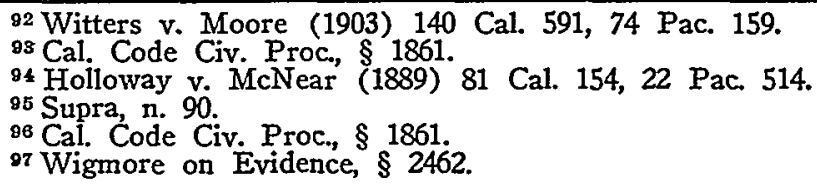


On the other hand, when you have the security of a local or class custom or habit of speech, it may be presumed that the writer conforms to the usage of his place or class when that is what a normal person in his situation would do." 98

The rule that should obtain in this State would seem to be settled and properly settled by the code section above referred to. ${ }^{99}$ If it can be shown that a certain term ordinarily having a plain meaning was actually "used and understood" by the parties in another sense, there would seem to be no objection on the ground of expediency or policy to the admission of evidence tending to prove that fact. Especially is this true in view of the fact that the code specifically provides that the terms employed in a writing are presumed to have been used "in their primary and general acceptation," and that such a presumption is itself evidence that must be weighed against the evidence of the special meaning attributed to the language used. ${ }^{100}$ The rule was correctly stated by the Supreme Court in the recent case of Shean v. Weeks: :101

"The ordinary meaning of words cannot be changed except by proof of general usage by those engaged in the particular trade, or by proof that the parties to the contract used them in the special sense contended for."

It will be noted that the court states that "proof of general usage by those engaged in the particular trade," or in the alternative, proof of an express intent on the part of those using the language in question is essential to vary the plain meaning of the terms employed. In the former case, a knowledge of the special usage will be presumed. When the usage is not general to those engaged in the particular trade, an intent to use the language in the special sense contended for must be shown.

This distinction is generally recoguized, ${ }^{102}$ although it is sometimes overlooked, as seems to have occurred in the drafting of the opinion in the recent case of Van DeGrift v. Mullen. ${ }^{103}$

Even though an ambiguity appears in the language of a

98 The Theory of Legal Interpretation, 12 Harvard Law Review, 417, 420 .

99 Supra, n. 93.

100 People v. Milner (1898) 122 Cal. 171, 54 Pac. 833; Thompson v.

Davis (1916) 172 Cal. 491, 157 Pac. 595.

101 (1917) 176 Cal. 592, 596, 169 Pac. 231, 232. Pac. 975 .

10217 C. J. 458; Corey v. Struve (1911) 16 Cal. App. 310, 116

103 (July 8, 1919) 29 Cal. App. Dec. 173. 
writing, it is the general rule, with certain exceptions, that evidence of declarations of the intent of the parties to it is inadmissible. This rule is generally based on the ground that it would be dangerous to allow such evidence on account of the possibility of its being used by a jury as a rival subject matter of interpretation in disregard of the terms of the writing itself. ${ }^{104}$

It has also been suggested by Mr. Wigmore that the reason for the rule is the same as for the parol evidence rule itself; namely, that:

"When a transaction has been even voluntarily embodied in a single document, no other utterance of intent or will on the same subject can be given legal effect." 105

But since such statements of intent might conceivably be used solely for the purpose of throwing light on the language actually employed by the writer, it would seem that the explanation of Professor Thayer that the rule is based on the expediency of allowing such evidence is the sounder one.

The rule excluding proof of declarations of the intent of a testator has been embodied in our Civil Code.

"When, applying a will, it is found that there is an imperfect description, or that no person or property exactly answers the description, mistakes and onissions must be corrected, if the error appears from the context of the will or from extrinsic evidence; but evidence of declarations of the testator as to his intentions can not be received."106

To the rule excluding such declarations there are today two generally recognized exceptions. The first of these exceptions exists in cases where there are two persons or things equally answering the description, frequently referred to as cases of equivocation. The second exception exists in cases of misdescription.

In drafting the code section quoted above neither of these exceptions was recognized. Our Supreme Court admitted in the case of Estate of Dominici ${ }^{107}$ that in this respect our code provision is not in accord with the general rule. Hence, it was held that the rule "will not be extended therefore beyond its actual

104 Thayer, Preliminary Treatise on Evidence at the Common Law, p. 440.

105 Wigmore on Evidence, § 2471.

100 Cal. Civ. Code, § 1340 .

107 (1907) 151 Cal. 181, 90 Pac. 448. 
language and will be held to apply to the mere incidental fugitive utterances or declarations of intent, as distinguished from specific instructions, as to testamentary disposition, which it may be proved were given."

The same limitation has been placed on the code provision in the case of a misdescription of a legatee. ${ }^{108}$

The Supreme Court has recently set forth the limitations to which courts are subject in attempting to ascertain the intention of a writer. It was there stated that:

"No authority sustains the proposition that under the guise of construction or explanation a meaning can be given to the instrument which is not to be found in the instrument itself, but is based entirely upon direct evidence of intention independent of the instrument. It has been well said that in the admission of extrinsic evidence, the line which separates evidence which aids the interpretation of what is in the instrument from direct evidence of intention, independent of the instrument, must be kept steadily in view, the duty of the court being to declare the meaning of what is written in the instrument and not what was intended to be written." 108

In this somewhat summary review of our decisions on the subject discussed, one fact must have been observed. The codification of the so-called parol evidence rule has not prevented our courts from following the general trend of the decisions in the other states, at times in complete disregard of the intent of those who framed our code provisions. Nor has such codification prevented our courts from laying down certain heterodox principles which the plain language of the code would seem to have rendered unnecessary.

Robert L. McWilliams.

San Francisco, California.

108 Estate of Little (1915) 170 Cal. 52, 148 Pac. 194.

109 Payne v. Commercial Bank of Los Angeles, supra, n. 70. 